\title{
EMPOWERMENT OF RURAL WOMEN FARMERS AND FOOD PRODUCTION IN RATHNAPURA DISTRICT IN SRI LANKA: A HOUSEHOLD LEVEL ANALYSIS
}

\author{
S D D Rathnachandra \\ Faculty of Agricultural Sciences, Sabaragamuwa University of Sri Lanka. \\ dilinirathnachandr92@gmail.com
}

\begin{abstract}
Women empowerment and gender equity are two significant aspects of the sustainable development of a country. As Sri Lanka is on the way towards sustainable development, this study was conducted to assess the situation of women farmers' empowerment and food production in Rathnapura district of the country. A sample of 300 women farmers was randomly selected for the study, from two selected Divisional Secretariat (DS) of Rathnapura district. Data was collected from a field survey using a pre-tested, self-administered questionnaire survey from April to July 2019. Empowerment was analyzed using the empowerment framework used by RAHMAN AND NAOZORE in 2007 in the study of "Women Empowerment through Participation in Aquaculture" with necessary modifications. Data analysis was conducted using descriptive statistics, correlation analysis and multiple linear regression analysis. Results revealed that majority of the women farmers were middle aged, married and had children. Furthermore, most of them had education up to secondary level. While average family size was four, average farm size was 1.25 acres. They had around 16 years of farming experience. The average monthly income of them was 25,000.00 LKR whereas $20 \%$ of it was from agriculture. The main sources of empowerment of women farmers were the Agrarian Service Center (55\%) followed by village organizations/societies (30\%) and microfinance institutions (26\%). Furthermore, women empowerment index was 0.65 . It is a moderate level of empowerment. However, there were women farmers under three categories of empowerment levels: low empowerment (4.1\%), medium empowerment (58.5\%) and high empowerment (36.1\%). Out of the socio-economic factors; age, education, family size, land size, number of training programs participated, monthly income, experience in agriculture and number of organizations participated, education and number of training programs attended had significant and positive effect for the empowerment. Accessibility of credit facilities and agricultural extension program participation showed that there was a considerable impact on food production rather than the cultivable land size and utilization of modern farming technologies for food production. Therefore, proving of timely important agricultural education and training programs, enhance awareness level of modern farming technology utilization, better micro finance programs and agricultural credit facilities will be able to enhance the empowerment level of the women farmers of this area furthermore.
\end{abstract}

Keywords: Women empowerment, sustainable development, gender equity, farming activities, Sri Lanka (JEL Code: Q01, Q12)

\section{INTRODUCTION}

The women empowerment is a basic concept according to the Developmental Goals (DG) to the emergence of poverty alleviation programs in a particular country (IBHARHOKANRHOWA, 2016). Women empowerment is a process of enhancing the freedom of decision making within the family, access to assets and resources, social participation, freedom of mobility and spending ability (RAHMAN \& NAOZORE, 2007). The potentials for agriculture accountable for the buildup of a proper avenue to unleashed the well-being of people through food production.
In Sri Lanka, more than half of the working population is constituted of women. But only about $18 \%$ share constitute as employed women from the total working age population. And also, the highest unemployment rate of women reported within the rural sector rather than the other sectors of the country. Sri Lanka is predominantly an agriculturally based country with $82 \%$ of the households still in the rural sector. Women constitute $50.7 \%$ of the Sri Lankan population are considered to be a valuable resource potential needed to be in the rural agricultural sector. Women contribution to agriculture is gradually increasing to the national economy. Most of the 
Sri Lankan women are participated in agricultural sector rather than industrial sector (ANNUAL LABOR FORCE REPORTS, 2017). Measuring the empowerment status of rural women and food production is timely important to make future decisions for achieving the sustainable development related with Social, Economic and Environmental aspects. Most of the researchers are only focusing on measuring the women empowerment and diagnose the factors of behind the empowerment of women. But in this research mainly clarify about the women which engaging in farming activities how create deviation on agricultural sector through achieving the overall empowerment in the society. Rural women are highly contributed to the agricultural activities in Sri Lanka. But with most of them don't have necessary power and facilities to do the work well. In some households, men are working in cities. Women have to do household activities and also agricultural activities. If they have sufficient level of empowerment, they can contribute to rural development up to a significant level. However, it is necessary to identify the issues related to empowerment of women farmers. These are the key aspects which constitute the attention on this study. Therefore, this study was used to find out the situation of empowerment of women farmers and also what are sources of empowerment relevant to the women famers in the study area. Empowerment calculated by using five dimensions according to the literature findings relevant to the field of empowerment.

\section{Food security and production in a global point of view}

The concept of food security is a target goal of United Nations Sustainable Development which valid during the period of 2015 - 2030. Most of the developing countries have common critical issue, such as unavailability of foods for the consumption or food insecurity. According to the demonstrations of the World Food Conference, evidence that wide range of crop failures and disasters causes for food insecurity (FAO, 2018). MAXWELL AND SMITH (1996) recorded about the other factors which are responsible for food insecurity. such as,

- Shortages of agricultural production and supply.

- Problems associated with the employment and wages.

- Health and morbidity related problems.

- Market status and price fluctuations.

This observation brings in a broader thinking about food security including the accessibility to consume insufficient quantity or quality of foods within the society. Household level food security demonstrate about the availability of food structures within the households to eradicate the crises related to low level of food consumption of women and other family members (NEGIN et al., 2009). Food security is the availability of adequate amount of food and ability to access to the expected proportion of foods at right time by each and every individuals (IBHARHOKANRHOWA, 2016). The International Food Policy Research Institute (IFPRI) define food security based on the three sections, such as food production, food access and food utilization. Food security at household level refers to production of foods for their household consumption and earning additional revenue through selling of surplus to the market. But, rural women try to adapt to the latest opportunities and constraints regarding the production of foods while ensuring the adequate level of foods within their families (NEGIN et al., 2009).

Food security has been generally responsible to build up the sustainable development throughout the world. Because, United Nations already focused as a developmental goal in particular country.

\section{Accessibility of modern farm technologies and food production}

Farming is an aggregate concept which describing the entire process of crop cultivation: preparation of lands, planting, weeding, harvesting, and post-harvesting activities (IBHARHOKANRHOWA, 2016).

Women has less ability to participate in economic opportunities because they face a work related with social mission rather than the men. In most societies, women are responsible for most of the household supervision and caring and sharing of family members as well as rearing of small livestock. According to the FAO, 2015 report, Novel Sri Lankan Agriculture is suffering from several major problems. Such as,

- Low adoption of modern farming technologies

- Lower utilization of mechanization

- Higher level of cost of production and lower profitability

- Increases in post-harvest losses

- High amount of transportation cost

- Lower level of market-oriented products

- Poor level of value addition to primary agricultural products

- Low crop productivity

- Research \& Development in central government

- Less priority to extension

For developing countries, more potential benefits associated with Contract Farming (BELLEMARE, 2015). Because farm scale tends to be small, farmers are consist with poor level of awareness about the agricultural activities, total agricultural production and utilization of management technologies are less efficient, and infrastructure facilities such as transportation of agricultural inputs and production, and poor flow of information within the supply chain, contracting with a large agribusiness firm may be the only way of farmers can access higher-end markets and receive beneficial returns from it (WANG et al., 2014).

Generally two types of farming technologies used,

- Local farming technology.

- Modern farming technology.

Local technologies obtain small-scale manner, conducted simple operations, lower cost and build up with indigenous materials. When considering about the modern technology, is consist with large-scale, higher operating cost, overall operational activities conducted as profit-oriented and maintaining with complex operations (IBHARHOKANRHOWA, 2016). 


\section{Extension service and food production}

Rural economy basis with the Agriculture. Agricultural extension is the most prominent type of extension occurred in non-metropolitan areas (FAO, 2018). In other words, extension is a process related with an informal educational background focused toward the population in non-metropolitan areas. Extension process allows for several advices and dissemination of information to solve their existing problems. Extension aims to optimize the efficiency of the family farming activities, maintaining maximum level of food production and generally support to upgrade the standard of living and overall development of the farm family (IBHARHOKANRHOWA, 2016).

The basic objective of the extension is to build up a proper foundation for farmer's outlook by focusing their opportunities and threats. Extension is not centralized with physical and economic development of the non-metropolitan population. Agricultural extension agents, help to gain a sustainable development through disseminating knowledge with the rural people (FAO, 2018).

An improved information and knowledge flow within the agricultural sector support to improve the small-scale agricultural production and create a proper path way to optimize the production surpluses to the agricultural markets, increased rural livelihoods, optimizing quality and yield (MOJAKI \& KEREGERO, 2019). Rural farmers obtain with a very few information regarding the agricultural sector, but innovative modern knowledge occurring in research institutions, universities, public offices and libraries consist with poor level of dissemination. It causes to build up the poor linkages between research, extension, not for profit and non-profit organizations, libraries etc. (LWOGA et al., 2011). Most of the developing countries are suffering from gender inequality focused under millennium development goals, cause to increase the knowledge barrier for the women farmers (QUISUMBING et al., 2014).

\section{Access to credit facilities for food production}

The demand for agricultural credit facilities are prevalent by the socio-economic factors in most of the non-metropolitan areas of developing countries (YADAV \& SHARMA, 2015). Most of the low income farmers persuade to accessibility of credit facilities to minimize the financial hazards occurring with the fertilizer and agrochemicals in virtually all of the developing countries (REHMAN et al., 2015).

Research has provided a greater platform for the credit facilities to empower women in taking decisions within the household, having proper social networks, having proper access to financial and economic resources, more bargaining power with their husbands within the family and having considerable freedom of mobility. However, women still suffering from various difficulties for the accessibility of such kind of credit facilities. The major case of lower accessibility of credit facilities, the rural women has low level of literacy and dependent on their husbands for agricultural inputs (IBHARHOKANRHOWA, 2016). Agricultural credit obtains with the several credit vehicles for financing the agricultural transactions, including loans, notes, bills of exchange and bankers' acceptances etc. These types of financing methods are supported to the specific financial needs of farmers, which are determined by planting, harvesting and marketing operations. In other words, credit is regarded as a major factor for the both agricultural development and rural development (MARTIN et al., 2014). Low interest rates of credit facilities for the purchasing of agricultural productive inputs, deviations of a traditional practice (tenure farming). Therefore, to obtain a significant improvement in food production, good agricultural credit system is an essential requirement. The government policy makers are focusing to bloom the sustainable financial system for the development of the agricultural sector. It cause to build up the accessibility of credit and other financial services (including banking) to the rural farmers (WORLD BANK, 2019).

\section{RESEARCH METHODOLOGY}

This research was conducted in Rathnapura district of Sri Lanka where many agricultural activities are performed. Questionnaire Survey used as the primary data collection method. The respondents of the research were the women farmers in Rathnapura district.

Around 1200 women farmers obtained in Rathnapura district. Among them, 300 women farmers were randomly selected for the study. Two DS divisions were selected according to the base of the purposive sampling technique across the 17 DS divisions in the study area.

Pre-tested self-administrated structured questionnaire was used as the data collection instrument of the study. Descriptive statistics and regression analysis were conducted as the data analysis method using SPSS software version 23. A pilot study was undertaken with 10 copies of the questionnaire to avoid ambiguity in further data collection process.

Table 1: Measurement of selected empowerment dimensions

\begin{tabular}{|c|c|c|c|}
\hline Empowerment & Number of & $\begin{array}{l}\text { Assigned scores based on the } \\
\text { selected responses }\end{array}$ & Possible \\
\hline \multirow[t]{2}{*}{ Dimension } & indicators & & score \\
\hline & used & & range \\
\hline $\begin{array}{l}\text { Decision making } \\
\text { within the family }\end{array}$ & 10 & $\begin{array}{l}0 \text { - No influence, } \\
\text { 1- Low influence, } \\
\text { 2- Moderate influence, } \\
\text { 3- Full influence }\end{array}$ & $0-30$ \\
\hline Spending ability & 10 & $\begin{array}{l}0 \text { - No ability, } \\
\text { 1- Low ability, } \\
\text { 2- Moderate ability, } \\
\text { 3- Full ability }\end{array}$ & $0-30$ \\
\hline Access to resources & 8 & $\begin{array}{l}0 \text { - No access, } \\
1 \text { - Low access, } \\
2 \text { - Moderate access, } \\
3 \text { - Full access }\end{array}$ & $0-24$ \\
\hline Freedom of mobility & 7 & $\begin{array}{l}0 \text { - Not at all, } \\
1 \text { - Rarely, } \\
2 \text { - Occasionally, } \\
3 \text { - Frequently }\end{array}$ & $0-21$ \\
\hline Social participation & 7 & $\begin{array}{l}0 \text { - No participation, } \\
1 \text { - Seldom participation, } \\
2 \text { - Occasionally participation, } \\
3 \text { - Frequent participation }\end{array}$ & $0-21$ \\
\hline
\end{tabular}


A unit score was represented to make a comparison among the five selected measures of empowerment, by the following formula:

Formula 1: Unit empowerment score

Unit score of empowerment $=$

Mean score of a particular dimension

Maximum possible score of the dimension

Formula 2: Overall empowerment

Overall empowerment $=\underline{\text { Total empowerment }}$ Number of respondents

Formula 3: Empowerment Index

Empowerment Index $=\underline{\text { Total empowerment }}$

Total score of dimensions

Seven variables were selected to identify the relationship of rural women's empowerment through participation in agriculture. Such as: age, education level of the respondents, family size, and size of the farm land, number of training attended, experience in agriculture, number of participated organizations of the village, number of extension services used and number of credit facilities used.

\section{RESULTS AND DISCUSSION}

Socio-demographic profile of respondents: The sociodemographic factors related with the women farmers obtain in table 2. All the respondents were women; therefore, gender variable is missing in the below data.

Table 2: Socio-demographic profile of respondents

\begin{tabular}{|c|c|c|c|c|c|}
\hline Selected variable & No & $\%$ & Selected variable & No & $\%$ \\
\hline Age & & & No of children & & \\
\hline $20-29$ & 14 & 4.7 & 0 child & 9 & 3 \\
\hline $30-39$ & 45 & 15 & 1 child & 56 & 18.7 \\
\hline $40-49$ & 93 & 31 & 2 children & 133 & 44.3 \\
\hline $50-59$ & 81 & 27 & 3 children & 85 & 28.3 \\
\hline $60-69$ & 54 & 18 & 4 children & 27 & 9 \\
\hline $70-79$ & 13 & 4.3 & 5 children & 5 & 1.7 \\
\hline Marital status & & & Level of education & & \\
\hline Single & 8 & 2.7 & No formal education & 6 & 2 \\
\hline Married & 279 & 93 & Primary education & 47 & 15.7 \\
\hline Widowed & 13 & 4.3 & Secondary education & 242 & 80.7 \\
\hline Divorced & 0 & 0 & Tertiary education & 5 & 1.7 \\
\hline Husbands occupation & & & Family size & & \\
\hline Farmer & 125 & 41.7 & 1 member & 8 & 2.7 \\
\hline Clark & 22 & 7.3 & 2 members & 17 & 5.7 \\
\hline Driver & 41 & 13.7 & 3 members & 133 & 44.3 \\
\hline Defense worker & 19 & 6.3 & 4 members & 89 & 29.7 \\
\hline Trader worker & 55 & 18.3 & 5 members & 31 & 10.3 \\
\hline Machine operator & 13 & 4.3 & 6 members & 15 & 5 \\
\hline Labor & 25 & 8.3 & 7 members & 7 & 2.3 \\
\hline Monthly income & & & $\begin{array}{l}\text { Monthly income } \\
\text { from Agriculture }\end{array}$ & & \\
\hline $0-20000$ & 25 & 8.3 & $0-20000$ & 27 & 9 \\
\hline $20001-40000$ & 208 & 69.3 & $20001-40000$ & 273 & 91 \\
\hline $40001-60000$ & 67 & 22.3 & $40001-60000$ & 0 & 0 \\
\hline Husband's education & & & $\begin{array}{l}\text { Savings } \\
\text { (To purchasing of agricultural } \\
\text { inputs for next cultivation) }\end{array}$ & & \\
\hline No formal education & 8 & 2.7 & $0-1500$ & 9 & 3 \\
\hline Primary education & 41 & 13.7 & $1501-3000$ & 13 & 4.3 \\
\hline Secondary education & 247 & 82.3 & $3001-4500$ & 187 & 62.3 \\
\hline Tertiary education & 4 & 1.3 & $4501-6000$ & 91 & 30.3 \\
\hline
\end{tabular}

Source: Field survey May-June, 2019
As shown in the table 2, the average age of the respondents was 40 - 49 years indicating that they were matured adults, so they have ability of decision making when it comes to farming and other related household matters. Only $19.7 \%$ of the respondents were below 40 years. This is demonstrated from the findings as $4.7 \%$ belonged to the age group of 20-29 years. Consider as, less than 30 year's respondents are young $4.7 \%$, in years between 30 - 50 as middle age farmers $46 \%$ and more than 50 years farmers are adult farmers $49.3 \%$. According to the findings highest value represent as adult farmers. Marital status, above table demonstrated from the findings as $2.7 \%$ belonged to the single, married category present highest value $93 \%$ among other respondents. But in questionnaire obtain other two categories. Such as separated and divorced. There was not obtain valid cases in respondent sample for these two categories.

Most of the respondents have only 2 or 3 children. No children obtain as $3 \%$. Because of the 8 respondents were single and only 1 respondent in age 20-29 years they have not children. Respondents level of education, $80.7 \%$ of the respondents were obtain secondary education as highest category and pathetic situation behind these data, $2 \%$ of respondents were consist in no formal education category. Most of the husbands $82.3 \%$ of the respondents are obtain with secondary education, Primary education was $13.7 \%$, and only $2.7 \%$ of husband have not formal education.

The statistics on family size revealed that $29.7 \%$ of respondents have 4 persons within the family, $10.3 \%$ was obtained as 5 persons, $44.3 \%$ consist with 3 persons, 5\% occurred in 6 persons within their family. Monthly income, $91 \%$ of income obtain in Rs.20001-40000 highest income present category, Rs.0-20000 category was shows as $9 \%$

According to the household income and expenditure report -2016 rankings,

$0-10000$ income $=$ Extreme poor,

10001- 20000 income $=$ Poor

20001-40000 income $=$ Lower middle income,

40001-60000 income $=$ Upper middle income

Therefore, findings are indicated monthly income of the respondents and monthly income from agriculture obtain in lower middle-income category in the study area.

Sources of farm women empowerment: Analysis done by the using of Descriptive statistics-frequency analysis. Sources of empowerment variables are (a) Agrarian service center (b) village organizations/ Societies (c) Micro finance Institutions (d) Bank loans and loan providing institutions (f) Mass media (g) Neighboring farmers.

Table 3: An importance of the Sources for farm women empowerment

\begin{tabular}{llccc}
\hline Selected Source & Type of source & No & $\%$ & Rank \\
\hline Agrarian Service Center & Internal source & 80 & 55.2 & 1 \\
\hline Micro finances Institutions & External source & 44 & 30.3 & 5 \\
\hline $\begin{array}{l}\text { Bank loans \& loan providing } \\
\text { institutions }\end{array}$ & $\begin{array}{c}\text { External } \\
\text { sources }\end{array}$ & 38 & 26.2 & 6 \\
\hline $\begin{array}{l}\text { Mass Media (TV, Radio, } \\
\text { Newspaper) }\end{array}$ & External source & 48 & 33.1 & 4 \\
\hline $\begin{array}{l}\text { Village organizations/ societies } \\
\text { Neighboring farmers }\end{array}$ & Internal source & 75 & 51.7 & 2 \\
\hline
\end{tabular}

Source: Field survey May-June, 2019 
According to the findings in the Table 3, most of the respondents are identify Agrarian Service Center activities have better support to their empowerment. Least supported organization is bank loans and loan providing institutions. Because $81.4 \%$ of women farmers are not willing to access credit facilities. But Agrarian Service Center is a better internal source and mass media is a better external source.

Table 4: Dimensions of Empowerment

\begin{tabular}{lcc}
\hline Dimensions of Empowerment & $\begin{array}{c}\text { Mean value of each vari- } \\
\text { able respondents score }\end{array}$ & $\begin{array}{c}\text { Level of } \\
\text { Empowerment }\end{array}$ \\
\hline $\begin{array}{l}\text { Decision making ability within } \\
\text { the family, }\end{array}$ & 20.22 & 0.16 \\
\hline
\end{tabular}

Family household expenditure

Agricultural production activities

Buying and selection of agricultural inputs

Marketing of agricultural products

Family health issues

Education of children,

Selecting and using family planning methods

Constructing and repairing of houses

Celebration of social and religious events

Giving loans to others

\begin{tabular}{lll}
\hline Spending ability & 17.85 & 0.14 \\
\hline
\end{tabular}

Spending money on agricultural activities,

Expenditure on Medicare and health

Sending money on children's education.

Buying household food items

Purchasing and selling of land and other assets

Buying household furniture and other items

Lending and borrowing money

Providing financial help to others

Spending money for social functions

Making donations to charity

\begin{tabular}{lll}
\hline Access to assets and resources & 13.22 & 0.10 \\
\hline
\end{tabular}

Access to family income and resources

Access to land and farm lands

Access to valuable instruments and machinery

Access to a bank (e.g. having their own bank account)

Access to credit facilities in institutions

Ability to contact public services (health, nutrition, education etc.)

Access to farm management and budgeting

\begin{tabular}{lll}
\hline Freedom of mobility & 14.75 & 0.11 \\
\hline
\end{tabular}

Market place,

Friends and relatives' houses outside the home village,

Agrarian Service Center

The neighboring houses

Capital city

Other districts

Grama Niladhari office

Religious places

$\begin{array}{lll}\text { Social participation } & 16.67 & 0.13\end{array}$

Participation in training and education programs

Participation in village organizations, meetings and arbitrations

Participation in social functions such as marriage cultural

programs, religious activities etc.

Helping neighbors in crisis situations

Working with people in emergency situations (such as natural disasters)

Arbitration in the conflicts of neighbors and family

Casting votes in local and national elections without outside interference.

Source: Field survey May- June, 2019
Based on each dimensions,

Overall empowerment $=82.73$

Empowerment Index $=0.65$

According to the findings $58.5 \%$ of women were obtained in medium empowerment situation. Sample shows that $0 \%$ obtained in very low empowerment, $4.1 \%$ of respondents were indicated as low empowerment and $36.1 \%$ of respondents are high empowerment situation (Categories are based on the RAHMAN \& NAOZORE, 2007)

Table 5: The contribution of five empowerment dimensions to overall empowerment score based on the stepwise multiple regression analysis

\begin{tabular}{lllll}
\hline Model & $\begin{array}{l}\text { Dimension } \\
\text { entered }\end{array}$ & Multiple R & $\begin{array}{l}\text { Coefficient of } \\
\text { determination R2 }\end{array}$ & $\begin{array}{l}\text { Percentage } \\
\text { of variation }\end{array}$ \\
\hline 1 & $\begin{array}{l}\text { Freedom of } \\
\text { decision making } \\
\text { within the family }\end{array}$ & 0.871 & 0.756 & 75.6 \\
\hline 2 & $\begin{array}{l}\text { Social } \\
\text { participation }\end{array}$ & 0.927 & 0.857 & 10.1 \\
\hline 3 & $\begin{array}{l}\text { Access to } \\
\text { resources }\end{array}$ & 0.967 & 0.935 & 7.8 \\
\hline 4 & $\begin{array}{l}\text { Freedom of } \\
\text { mobility }\end{array}$ & 0.985 & 0.970 & 3.5 \\
\hline 5 & Spending ability & 0.99 & 0.99 & 3.0 \\
\hline
\end{tabular}

Source: Field survey May- June, 2019

Among five dimensions, freedom of decision making within the family had been explained the highest percentage variation in the empowerment score. And also, spending ability showed the lowest percentage variation on the empowerment score.

Factors affecting women Empowerment: Analysis done by the using of Descriptive statistics and step wise multiple regressions analysis. Independent variables are age, education in years, family size, Land size, number of training attended, monthly income, experience in agriculture in years, number of participated organizations in the village, number of extension services used, number of credit facilities used dependent variable is empowerment score. Other factors which are relevant to the empowerment score, consider their relationship strong from the correlation coefficient $(r)>0.05$.

Table 6: Relationship determination between the rural women's empowerment and selected predictable variables

\begin{tabular}{lc}
\hline Independent variable & Correlation coefficient (r) \\
\hline Education & 0.644 \\
Size of the farmland & 0.376 \\
Experience in Agriculture & 0.121 \\
No of organizations participated & 0.243 \\
No of training attended & 0.477 \\
Age & 0.307 \\
Monthly income & 0.136
\end{tabular}


Table 7: The variation of women's empowerment score to the selected predictable variables based on the stepwise multiple regression analysis.

\begin{tabular}{clccc}
\hline Mode & Variable & Multiple R & $\begin{array}{l}\text { Coefficient of } \\
\text { determination } \\
\text { R square }\end{array}$ & $\begin{array}{l}\text { Percentage } \\
\text { variation } \\
\text { expressed }\end{array}$ \\
\hline 1 & Education & 0.734 & 0.620 & 62 \\
2 & $\begin{array}{l}\text { No of training } \\
\text { attended }\end{array}$ & 0.779 & 0.601 & 60.1 \\
3 & $\begin{array}{l}\text { Size of the } \\
\text { farmland }\end{array}$ & 0.793 & 0.536 & 53.6 \\
4 & Monthly income & 0.799 & 0.628 & 62.8 \\
\hline
\end{tabular}

Source: Field survey May- June, 2019

Monthly income of the respondents had been explained highest percentage variation as $62.8 \%$, Education represent the $62 \%$ variation and number of training attended indicate as $60.1 \%$ variation. Therefore, monthly income, number of training attended, education and size of the farm land affect for the empowerment of person.

Impact of the cultivable land size and food production: Research findings were noted as $50.7 \%$ of respondents had less than 0.5-acre size of farm land and 2-acre size was the largest acreage of farm land that showed by the respondents $2.8 \%$ within the study. Cultivable land size and food production impact were assessed through the chi-square analysis. The P-value of Pearson Chi-Square value is 0.007 which is less than the significance level (0.05). And also, the relationship is moderate $68.7 \%$, we conclude that there is an association between cultivable land sizes to the food production in the study area. Even though the farm land size increases food production may be less, the way of using agricultural inputs, farming experiences of the respondents, location of the farm land and soil structures and adequate agricultural extension services. According to the findings of the SRABONI at al., 2014 noted that household food security varies by the size of the farm land owned by the household.

Impact of utilizing modern farming technologies and food production: Most of the respondents had less than 1-acre farmland and utilization of modern farming technologies obtained as considerably very low in the study area. Therefore, hybrid seeds, hybrid seedlings, ploughing equipment and plant growth regulators were used as the modern farming technologies in the study area. Research findings showed that $53.3 \%$ of respondents utilize modern farming technologies while doing their cultivations and $46.7 \%$ of respondents were not use any kind of modern farming technique for their cultivations. Utilization of modern farming technologies and food production impact were assessed through the chi-square analysis. The P-values of Pearson Chi-Square value is 0.08 and Cramer's chi-square value 0.08 which is not less than the significance level (0.05). And also, the relationship is at lower level $38.7 \%$, we conclude that there is not a considerable association between utilization of modern farming technologies to the food production in the study area. Based on the findings of the IBHARHOKANRHOWA, 2016; FAO, 2013 showed that utilization of modern farming technologies increases the quantity of food produced by the rural women farmers.
Impact of agricultural extension program participation and food production: Agricultural extension services are available for most of the respondents $62.1 \%$ in the study area, as only $39.9 \%$ of respondents were found to have not ever attended an agricultural training. Reasons were sought from other respondents on why they have not participated any agricultural extension training. There are four factors to justify their absence for the agricultural extension programs. Such as (a) Not registered in the any agricultural organization (b) Financial constraints (c) Not invited for any one (d) Not important to me (e) Not enough time. Among them most of the respondents $50.4 \%$ answered as not registered in any agricultural organization.

Agricultural extension program participation and food production impact were assessed through the chi-square analysis. The P-values of Pearson Chi-Square value and Cramer's V test is 0.000 which is less than the significance level (0.05). And also, the relationship is very strong (0.977), we conclude that there is an association between agricultural extension program participation and farmer education to the food production in the study area. Chi-square analysis of the relationship between Agriculture extension services accessibility and food production. But according to the ABBEAM et al., 2018; IBHARHOKANRHOWA, 2016 findings, agricultural extension services have impacted positively on food production capacity of rural women farmers.

Impact of credit accessibility and food production : Access to credit facilities was found to be low as only $18.6 \%$ respondents and many of those who did not access loan reported that they had fear of inability to repay $49 \%$, the frustration that comes from the bank's demand for collateral $18.6 \%$, and higher interest rate from the bank $28.3 \%$. Most of the respondents among those who access loan facilities, reported as loan accessed before one year ago or two year ago. Because, most of the respondents find initial capital through bank loans. After that they keep savings to the purchasing of agricultural inputs to the next cultivation. And also, those access loan, $7.6 \%$ of respondents' highest category present as Rs.2500050000. Rarely reported more than Rs.50000 loan amount. Impact of loan accessibility on food production revealed that all the respondents $11 \%$ who had obtained the loan for a period of one or more years reported increase in food production as less than double. 5.5\% respondents reported as convert their food production double after the credit accessibility. Only 1 respondent indicate as increase their food production more than double. The other respondents reported as no increase from their loan without fully utilization of it. Because it has been less than a year ago. The women responded that lack of access to finance remains a considerable barrier to their food production as they need necessary funding to be able to purchase agrochemicals, fertilizers, pay for farm labor and so on. The results show that rural women farmers cannot increase to significant level of their food production even if they access to credit facilities.

Credit accessibility of respondents and food production impact were assessed through the chi-square analysis. The P-values of Pearson Chi-Square value and Cramer's V test 
is 0.000 which is less than the significance level $(0.05)$. And also, the relationship is very strong (0.954), we conclude that there is an association between credit facilities accessibility and food production in the study area. Based on the findings of the IBHARHOKANRHOWA, 2016; AINA, 2012 showed that accessibility of credit facilities increases food production among rural women farmers.

\section{CONCLUSION}

This study revealed that women farmers in Rathnapura district are medium empowered in their efforts in food production. Decision making ability within the family involves to contributing more weight to the empowerment than the other factors. Such as, spending ability, social participation, access to assets and resources and freedom of mobility. Other factors which are responsible for the empowerment are highlighted as education, monthly income and number of extension services participated. Under impact on empowerment, lower access to modern agricultural techniques engendered by improper institutional participation failures. They have not enough money to spend for the modern farming equipment and poor knowledge about the innovative agriculture.

However, When considering about the constraints regarding the empowerment of by women farmers as land ownership and accessibility aspects of it. Because most of the women farmers gain their farmland through their husbands. Accessibility of credit facilities and agricultural extension program participation showed that there was a considerable impact on food production rather than the cultivable land size and utilization of modern farming technologies for food production.

\section{REFERENCES}

Abbeam G. D., Ehiakpor D. S., \& Aidoo R. (2018): Agricultural extension and its effects on farm productivity and income: insight from Northern Ghana. Agriculture \& Food Security, 7(74). doi:https://doi.org/10.1186/s40066-018-0225-x

Aina O. I. (2012): Two halves make a whole: Gender at the Crossroads of the Nigerian Development Agenda. An Inaugural Lecture Delivered at the Oduduwa Hall, Obafemi Awolowo University, Ile-Ife, Nigeria. Obafemi Awolowo University Press Limited.

Annual Labor Force Report. (2017): [Accessed on 04/07/2020]. Available at: http:// www.statistics.gov.lk/samplesurvey/LFS Annual\%20 Report 2016.pdf

Bellemare M. F. (2015): Contract Farming: What's In It for Smallholder Farmers in Developing Countries? Agricultural \& Applied Economics Association, 30(3). Retrieved from http://www.choicesmagazine.org
Central Bank Reports. (2018): Economic social science statistics. [Accessed on 04/07/2020]. Available at:https:// www.cbsl.gov.lk/en/publications/economic-and-financialreports/annual-reports/annual-report-2018.

Food and Agricultural Organization of the United Nations (FAO)(2013): Forests, food security and gender: linkages, disparities and priorities for action. Background paper for the International Conference on Forests for Food Security and Nutrition Forests for Food Security and Nutrition. World Bank. Available at: http://www.fao.org/publications/ sofa/2013/en/

Food \& Agriculture Organization reports(FAO),.(2015): [Accessed on 04/07/2020]. Available at: http://www.fao.org/ publications/sofa/2015/en/.

Household income and expenditure survey reports,. (2016): [Accessed on 04/07/2020]. Available at: http://www.statistics. gov.lk/ agriculture/

Ibharhokanrhowa o. m. (2016): Empowerment of Rural Women Farmers and Food Production in Esan West Local Government Area of Edo State, Nigeria. A Thesis Submitted in Partial Fulfilment of the requirements forthe Degree of Doctor of Philosophy (Ph.d) in Sociology to the Department of Sociology, College of Business and Social Sciences Covenant University . Available at: http://eprints. covenantuniversity.edu.ng/8494/1/ozoya\%20mercy\%20i\%20 phd\%20thesis.pdf

Lwoga E.T., Ngulube P. and Stilwell, C., (2011): Access and use of agricultural information and knowledge in Tanzania. Library Review 60(5): 385-395. http://www.emeraldinsight.com/

Martin O. (2013): The African Union's mechanisms to foster gender mainstreaming and ensure women's political participation and representation. Sweden: International IDEA.

Maxwell S. Smith M. (1996). Food security: A post-modern perspective. Food Policy 21(2), 155-170.

Millenium Development Goals reports,. (2015): [Accessed on 04/07/2020]. Available at:https://www.un.org/ millenniumgoals/2015_MDG_Report/pdf/MDG\%202015\%20 rev\%20(July\%201).pdf

Mojaki R. A., \& Keregero K. (2019): Turning challenges into opportunity: Potential for adoption of e-extension in Lesotho. Journal of Agricultural Extension \& Rural Development, 11(11), 184-191. doi:https://doi.org/10.5897/JAERD2019.1040

Negin J., Remans R., Karuti S., \& Fanzo J. C. (2009): Integrating a broader notion of food security and gender empowerment into the African Green Revolution. Food Security, 1, 351-360. doi:10.1007/s12571-009-0025-z 
Quisumbing A. R., Dick R. M., Raney T. L., Croppenstedt A., Behrman J. A., \& Peterman A. (2014): Gender in Agriculture: Closing the Knowledge Gap. The Food and Agriculture Organization of the United Nations \& Springer Science. doi: 10.1007/978-94-017-8616-4

Rahman H., \& Naoroze K. (2007): Women empowerment through participation in Aquaculture: Experience of e large scale technology Demostrain project in Bangladesh. . Journal of social science.

Rehmana A., Jingdong L., Shahzad B., Chandio A. A., Hussain I., Nabi G., \& Iqbal M. S. (2015): Economic perspectives of major field crops of Pakistan: An empirical study. Pacific Science Review B: Humanities and Social Sciences, 1(3), 145-158. doi:https://doi.org/10.1016/j.psrb.2016.09.002.

Sraboni E., Malapit H. J., Quisumbing A. R., \& Ahmed, A. U. (2014): Women's empowerment in agriculture: What role for food security in Bangladesh? World Development, 61, 11-52.

Wang H.H., Y. Wang and M.S. Delgado. (2014): “The Transition to Modern Agriculture: Contract Farming in Developing Economies," American Journal of Agricultural Economics 96(5): 1257-1271.

World Bank. (2019, September 23): Agriculture Finance \& Agriculture Insurance. [Accessed on 04/07/2020]. Retrieved from https://www.worldbank.org/en/topic/financialsector/ brief/agriculture-finance.

Yadav P., \& Sharma A. K. (2015): Agriculture Credit in Developing Economies: A Review of Relevant Literature. International Journal of Economics and Finance, 7(12), 219244. doi:10.5539/ijef.v7n12p219. 